\title{
EXECUTIVE COMPENSATION AND FIRM PERFORMANCE:EVIDENCE FROM AN EMERGING COUNTRY
}

\author{
YÖNETICIILERIN ÜCRETLENDİRILMESİ VE FİRMA PERFORMANSI: \\ GELISSMEKTE OLAN ÜLKE ÖRNEĞİ
}

\author{
Levent ATAÜNAL ${ }^{*}$ \\ Aslı AYBARS ${ }^{* *}$
}

\begin{abstract}
Shareholders delegate daily operation to their agents with the assumption that they would work totally for their benefit. However, individual efforts of agents are not directly observable by the principal (shareholders). To align the interests of agents and those of shareholders, compensation schemes are based on either market or accounting measures (or a combination of the two). This paper, using longitudinal data of 151 listed Turkish firms over the years of 2006 to 2015, found that total compensation amount paid to executives and directors is sensitive to both accounting and market measures. It is revealed that current year net profit and lagged total shareholder value created played important role in the determination of compensation level of executives. The estimations revealed that TL 10,000 return provided to shareholders in the previous year caused TL 5 increase in executives' total compensation, whereas TL 2 of TL 1000 current year net profit of the firms is given to the executives. It is believed that compensation contracts which are sharing only a fraction of created shareholder value with the agent cannot align the interests of both parties and fully mitigate the agency problem.
\end{abstract}

Keywords: Compensation, Agency theory, Performance measures

Jel Codes: G30, G32, J33

Öz

Sermaye sahipleri (patronlar) kendi şirketlerini yönetmesi için çalışanları işe almakta ve bu çalışanların (vekil) sermayedarın çıkarları doğrultusunda hareket edeceklerini varsaymaktadırlar. Ancak vekillerin çalışmalarının patron tarafından sürekli olarak gözlemlenmesi mümkün değildir. Patron ve vekilin çıkar birliği genellikle ücret sözleşmesine konan piyasa ve/veya muhasebe sonuçları ve bunlara dayalı ücret sözleşmeleri ile sağlanmaya çalışılır. Bu çalışma Borsa İstanbul'a kayıtlı 151 şirketin 2006 ve 2015 yılları arasındaki verilerini

* Dr, Istanbul Aydin University, Faculty of Economics and Administrative Sciences, leventataunal@aydin.edu.tr

** Associate Professor Dr., Faculty of Business Administration, asli.aybars@marmara.edu.tr 
inceleyerek, vekil yöneticilerin ücret sözleşmelerinin hem muhasebe sonuçlarına hem de piyasa verilerine dayandırıldığını bulmuştur. Özellikle fiili yıl muhasebe sonuçları ve geçmiş yıl piyasa verilerine dayalı yaratılan hissedar değeri, yöneticilerin ücretlerinin belirlenmesinde önemli rol oynamaktadır. Araştırmanın sonuçlarına göre geçmiş yılda hissedarlara sağlanan her 10,000 TL’lik ek değer yöneticilere sağlanan ücretlerde yaklaşık 5 TL'lik artışa neden olmaktadır. Ayrıca fiili yıl net karındaki her 1000 TL'lik artış yöneticilerin aynı yılki ücretlerinde yaklaşık 2 TL'lik artışa neden olmaktadır. Yaratılan toplam değerin ancak küçük bir kısmını vekiller ile paylaştıran ücret sözleşmelerinin tam bir çıkar birliği sağlaması ve vekalet sorununu çözmesi beklenmemektedir

Anahtar Kelimeler: Ücretlendirme, Vekalet teorisi, Performansı ölçüleri

Jel Kodları: G30, G32, J33

\section{Introduction}

Agency theory conjectures that the principal's major concern is maximizing his/her own wealth, that is the net present value of the company. Shareholders delegate daily operation to agents with the assumption that they would act on their behalf. Incentive problems arise because, in most circumstances it is not possible to directly observe individual efforts of agents. The compensation scheme is expected to align the interests of agents and shareholders (principal). Theoretically, the agent's pay bases on measures which are beneficial to the principal. Jensen and Murphy (1990) claimed that optimum contract could only be designed when shareholders had comprehensive information regarding the CEOs activities and firm's investment opportunities. They contended that incentive contracts would be redundant when CEO activities are perfectly observable. Some researchers suggested that compensation arrangements would at most be a partial remedy to the agency problem (Bebchuk and Fried, 2003, pp.72). An inappropriate contract may impose additional costs besides the face value of the contract by adversely impacting performance of the managers.

Efficient market hypothesis predicts that executives' actions are immediately reflected in the share price of the company, therefore stock market performance measures are accurate signals of executives' effort. However, making executive pay solely depend on stock market factors may not be effective when majority of the variation in stock prices is attributable to factors beyond firms' control (economy-wide factors) Conyon et al. (2000). Accounting based measures are preferred as they are not subject to shocks and they may protect the executive from noise induced by market factors. But, when compensation amount solely depends on accounting measures, it introduces an incentive for the agent to manipulate account figures for his or her own benefit. Sloan (1993), Conyon and Leech (1994) suggested that, although accounting earnings may not contain all relevant information, it may be adopted as the most appropriate way to measure agents' effort.

Currently, there is no theoretical or empirical consensus on how stock options and managerial equity ownership affect firm performance and how an optimal contract should be designed (Guay et al. 2003, pp. 34). McConnell and Servaes (1990, pp. 601-602) revealed a positive relationship between increases in ownership of agents and firm performance when managerial ownership is less than 50 percent. On the other hand, the causal direction of the link between equity incentives and 
performance is not clear (Guay et al. 2003; Kole, 1997). It is also possible that, rather than higher equity incentives producing performance improvement, firms anticipating better future offer more equity incentive.

Firms may pursue goals other than maximizing shareholder wealth since compensation may be linked to other measures such as market share or sales growth. Many empirical studies already investigated the relationship between managerial pay and firm performance. However, other than the studies in the United States where numerous studies exist on executive compensation and alignment between executive compensation and shareholder wealth, the number of studies in other emerging countries and Turkey are limited. The question of whether executive compensation schemes in emerging countries encourage executives to pursue shareholder benefiting goals is not fully answered yet. This study aimed to disclose the relation between executive pay and firm performance with a sample of listed firms from Turkey.

The rest of the paper is organized as follows. Section 2 reviews and briefly discusses literature concerning executive pay and performance relationship. Section 3 describes the data and the sample used in the study. Section 4 explains the methodology adopted. In Section 5 , the findings of the study are presented. Section 6, discusses results and concludes the paper.

\section{Literature Review}

Most of the employment contracts have both fixed and variable components. Salary represents the fixed part of the contract and is paid independent of level of performance. Bonus, on the other hand, frequently varies with the changes in the pre-defined performance measures. It is confirmed that cash compensation increases when firms' profits increase without any link to managers' efforts (Bebchuck and Fried, 2003; Blanchard et al., 1994; Bertrand and Mullainathan, 2001). The fixed part of compensation, cash compensation, has long been criticized for being insufficiently linked to performance of managers (Bebchuck and Fried, 2003, pp.76). Among the executives below top management, shareholder value based incentives are relatively less important (Guay et al. 2003, pp. 30).

Executive actions are difficult to monitor. Different actions of CEOs require different schemes for monitoring. As the agent theoretically owns less than 100 percent of the firm, he (she) has an incentive to consume perquisites, such as luxurious office, company car and jet aircraft. Agent gets all the benefits from the perquisite but bears only a fraction of the costs when partially owns the firm (Guay et al. 2003, pp. 31). When a CEO's perquisite consumption is the main concern, CEO percentage holding in the firm is more important. However, when we are more concerned about adoption of the right strategy, we should be more concerned about the CEO's total equity stake in the firm.

Choice of performance measures is an important component of the compensation contract. In defining variable part of compensation schemes, one approach is to link bonus amount to share price or company's market worth. Another possibility is to tie them to specific performance targets (market or accounting). Performance standards are typically based on budgets and/or prior-year performance, and often subject to board approval. But, some of the employees who are measured relative 
to the budget standard have influence over the budget's approval process. Budget-based performance standards create incentives to define lower standards to maximize bonus amount. On the other hand, when year-to-date performance suggests that annual performance will exceed the budget target to achieve the bonus cap, managers are inclined to reduce effort and put aside some earnings to use in the coming year. Likewise, when the expected performance is below the target, managers will be tempted to manipulate earnings.

Theoretically, market-based measures are forward-looking measures. They reflect market's anticipation on future profitability which is shaped by managements' decisions. However, accounting-based measures are backward-looking measures of performance (Canarella and Nourayi, 2008, pp. 540). Managers focused only on accounting profits may avoid actions that reduce current profitability but increase future profitability, such as research and development (Murphy, 1999; Dechow and Sloan, 1991). Besides, accounting profits can be easily manipulated, either through discretionary adjustments in "accruals" or by shifting earnings across periods (Murphy, 1999; Healy, 1985).

When a performance target is defined above market or industry average, it is unlikely for the average performer to receive any bonus. Nevertheless, majority of current compensation schemes are fabricated to benefit executives without creating the perception of excessiveness. In conventional compensation schemes, the amount of bonus is linked to absolute share price increase without any benchmarking with the competition or to absolute profit figure. During economic growth, executives can still earn sizable bonuses even when their companies under-perform relative to market average, (Bebchuck and Fried, 2003, pp.83-84). Additionally, managers are not supposed to undertake acquisitions that are value-decreasing. However, a larger firm size frequently results in higher compensation amount or growth is put as a performance measure on which bonus amount is based. Concisely, majority of compensation contracts are far from aligning shareholders' interests and managers' interests.

A common practice used by listed firms to align interests of the agents and the principals is giving stock options. As agency problem is expected to be mitigated through appropriate managerial incentives, stock option grants to executives have increased substantially in the recent years. Stock prices are affected from the market fluctuations induced by business cycles and the adopted economic policy in the country. Stock options do not isolate the pure efforts of the managers from the market conditions, thus enable managers enjoy stock price increases stemming solely from the market conditions. Besides, they do not fully represent the incentives from stock ownership. Options reward only stock-price appreciation and not total shareholder returns (which include dividends), executives holding options have incentives to avoid dividends. The value of options increase with stock-price volatility, executives with options have incentives to choose riskier investments (Murphy, 1999).

A linear payoff in compensation contracts induces risk-averse managers to reject risky, positive net present value (NPV) projects. Stock options partially solve this problem and add convexity to contracts (Guay et al. 2003, pp. 33). But added convexity results in considerable payments at high levels of stock price, and nothing below the strike value (Harris and Bromiley, 2007). Thus, to reach an optimal contract, firms with greater growth opportunities has to offer more risk-taking incentives 
in the contract. Thus, increased use of stock option compensation sometimes creates more incentive alignment problems than it solves (Harris, 2009).

Empirical evidence confirmed the weak link between performance and pay. Jensen and Murphy (1990) found that, on average, USD 1,000 change in shareholder wealth corresponds to an increase in this year' and next year's salary and bonus of USD 0.02. They also reported that CEO performance incentives mainly come from stock ownerships, and bonuses represented 50\% of CEO's total compensation, but were not closely linked to market value changes and earnings.

Another problem with high percentage of bonus payments in the total compensation of the executives' package is that, it encourages executives for earnings management, in other words, cause them to manipulate the reported performance of the firm to trigger incentives. Harris and Bromiley (2007) verified that extremely low performance compared to average performance in the industry, and high level of stock options substantially increased the possibility of financial misrepresentation. Obviously, the motivating power of incentive pay overcomes any moral and corporate governance issues. For instance, a firm that pays over $92 \%$ of total CEO compensation as stock options has nearly a $40 \%$ chance of an accounting restatement in a sub - sequent 10-year period (Harris, 2009).

Determinants of pay level of executives, especially CEO compensation is an extensively studied topic in finance. In a typical empirical model analyzing CEO compensation, firm size and performance are generally adopted as the explanatory variables. Canarella and Gasparyan (2008, pp. 552) showed that in "new economy" industries, the impact of firm size on CEO compensation is robust to alternative specifications of the error structures. Canarella and Nourayi (2008, pp.546-548) suggested that the relationship between executive compensation and firm performance is non-linear and asymmetric. A positive link between growth opportunities and CEOs' equity incentives are found (Guay et al., 2003; Gaver and Gaver, 1993; Mehran,1995; Himmelberg, et al.,1999; Palia, 2001).

Zhou (1999) found that the incentive strength associated with direct pay and stock ownership in Canadian firms is weaker than in US firms. The finding is explained by the fact that Canadian market is more closely regulated. Banghoj et al. (2010, pp. 498-501) examined determinants of executive compensation in privately held Danish firms. They found that that compensation level and performance relation is weak. Size and ownership concentration emerged as the leading variables that explained executives' compensation level. Executive characteristics like skills, title, and education only moderately explained the variation in executive compensation. It is also revealed that better designed bonus plans did not lead into better pay-to-performance relation.

Incentive compensation is also claimed to have an ambiguous relationship with firm performance that can reward executives for luck (Harris, 2009; Bertrand and Mullainathan, 2001), or encourage CEOs to manage their personal reputations rather than their organizations (Harris, 2009; March, 1984). Research indicates that current forms of managerial incentive pay do not effectively align the incentives of managers and shareholders. A number of studies could not demonstrate any positive link between executive incentive pay and improved performance of the firm (Harris, 2009; Mishra et al., 2000; Murphy, 1999), further to this some studies even suggested that CEO pay or perquisites might in fact negatively impact firm performance (Harris, 2009; Core et al. 1999; Yermack, 2006). 
During market booms shareholders are less likely to resist lavish payments to agents. Likewise, during market declines, they become parsimonious in expenses especially in bonus payments (Bebchuck and Fried, 2003).

On the other hand, long term compensation plans are claimed to be better functioning. Lifetime employment is expected to result in managers acting for the long-term benefit of the firm. Besides, short-term performance measures are generally too noisy (Ang and Constand, 1997). When effective monitoring mechanisms are established they generally reduce the need for performance-related pay (Banghoj et at, 2010).

\section{Data and the Sample}

The dataset of this study consisted of observations of 151 BIST (Borsa Istanbul) firms collected between 2007 and 2015. Financial firms and banks are excluded as they are subject to strict legal restrictions. To avoid survivorship bias only firms with consecutive available data are included into the sample. As some calculations engaged lag values, final sample used in the regressions included only the observations between 2008 and 2015. The data for total executive compensation, base pay and bonus, are obtained from the firms' annual reports.

In Figure 1, annual means of total executive compensation is exhibited between the years 2008 and 2015. Average total compensation of top executives is constantly increasing over the years. In 2008 average total compensation is slightly under TRL 4 million. But it more than doubles in the next seven years and exceeds TRL 8 million in 2015. This noteworthy increase probably stems from both salary increases due to inflation and growth in the companies, which bring in expansion in the number of executives and directors. Increase in size augments complexities in firms and may entail additional workforce and/or more talented executives. On the other hand, average total executive compensation per unit asset builds up until 2010 then decreases (Figure2). It is probably caused by the shrinkage in firm size in 2008, 2009, and 2010 due to global recession. After 2010 firms seem recover their healthy growth. When firms shrink in size, they cannot reduce their management force at the same pace.

Figure I

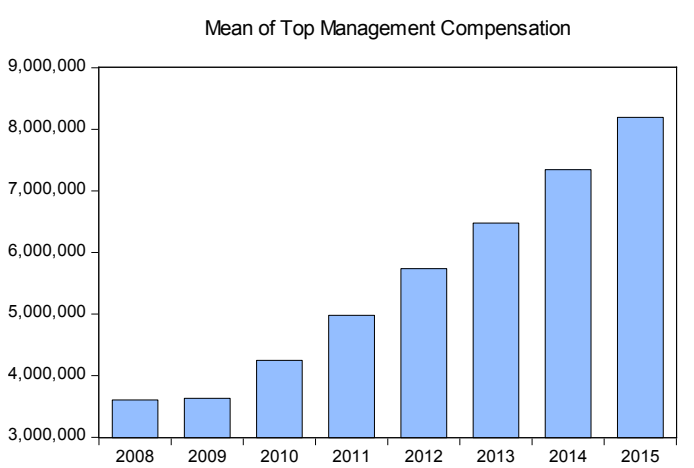

Figure 2

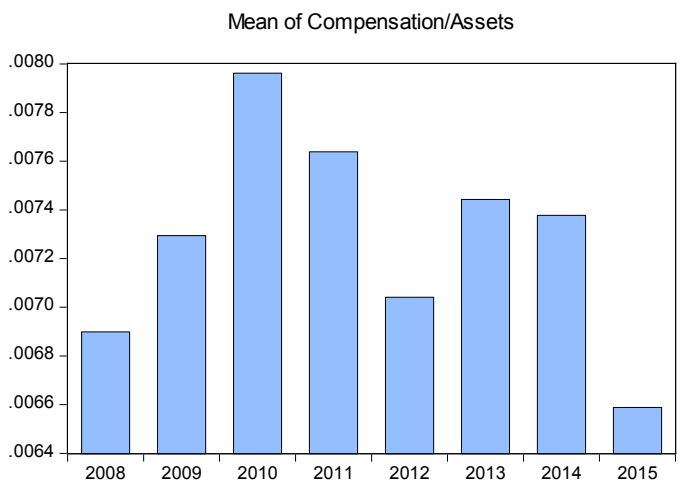


Volatility in total shareholder value created and net profit result in fluctuations on compensation per shareholder value created and compensation per profit (Figure 3 and Figure 4). This fluctuation clearly is not caused by the volatility in total compensation level. Pay contracts of top executives generally consist of base pay and bonus. Base pay is paid independent of the performance level. However, bonus is generally tied to specific performance measures. Naturally, in a calendar year, total compensation never goes down to zero.

Figure 3

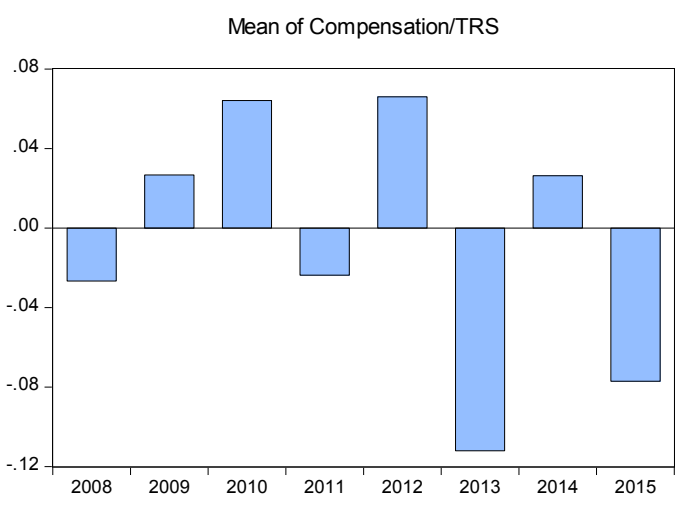

\section{Figure 4}

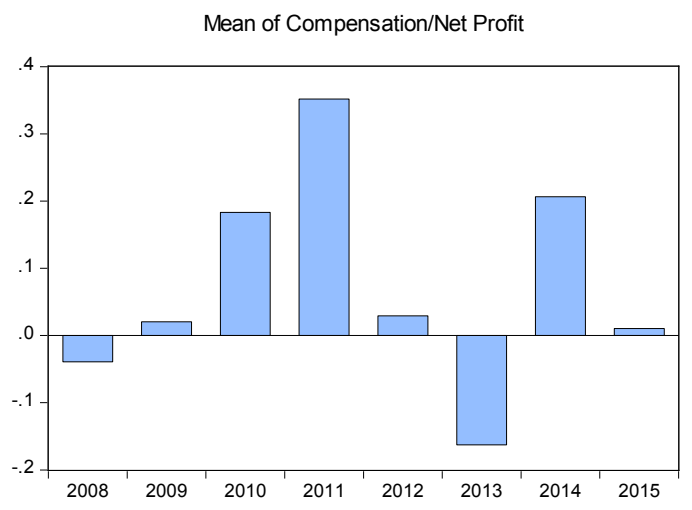

\section{The Methodology}

The study aimed to reveal whether executive compensation is linked to accounting performance and/or shareholder wealth and the level of sensitivity of each performance measure. Two alternate approaches are mentioned in literature for determining factors that affect compensation level of executives. First is the "elasticity" approach, where the level of (or the change in) the log of compensation is linked to the level of (or the change in) the log of firm performance. Second is the "sensitivity" approach, which links the level of (or the change in) compensation to the level of (or the change in) firm performance (Jensen and Murphy, 1990; Zhou, 1999; Canarella and Gasparyan, 2008). In this study sensitivity approach is adopted. The primary advantage of the sensitivity approach is that it is easier to interpret.

The pay-performance sensitivity represents the executives' benefit from the measured performance. Since agency costs occur when agents receive less than the whole of the value created in the firm, the "sharing rate" of the total value created is accepted as a natural measure of the severity of the agency problem. Elasticities have no corresponding "agency-theoretic interpretation" (Murphy, 1999). Murphy (1999) claimed that, neither of the approaches dominated the other. In measuring performance of executives both accounting and market measures are adopted. Accounting-based performance measures are less likely to be affected by the noise of the market, but market-based measures are more relevant as they reveal complete performance of the firm as well as the future prospects. Sometimes, it takes time for compensation levels to adapt to their new equilibrium level. Lagged 
dependent variables are included in the equation to account for this fact (Conyon et al. 2000; Main et al, 1996).

The variables used in the study are given in Table 1.

Table I: The Variables and Their Abbreviations

\begin{tabular}{|l|l|}
\hline Dependent Variables & $\begin{array}{l}\text { Total amount of compensation paid to top executives and to the directors; such as salary and } \\
\text { performance bonuses by firm i in year } \mathrm{t}\end{array}$ \\
\hline Comp & \\
\hline Independent Variables & Net annual profit after tax of firm i in year $\mathrm{t}$ \\
\hline TRS $S_{i t}$ & $\begin{array}{l}\text { Total return to shareholders - Increase in market value of equity and distributed dividends ad- } \\
\text { justed for capital increase and share repurchases of firm } \mathrm{i} \text { in year } \mathrm{t}\end{array}$ \\
\hline
\end{tabular}

Following the sensitivity approach equation (1) is solved

$\Delta$ Comp $_{i t}=\beta_{0}+\beta_{1}$ Net_profit $_{i t}+\beta_{2} T R S_{i t}+\beta_{3} N_{\text {Net_profit }}, t-1+\beta_{4} T R S_{i, t-1}+\varepsilon_{i t}$

\section{Results}

Correlations between explanatory variables are given in Table 2. Multicollinearity significantly affects signs and magnitude of estimated coefficients in a regression estimation. The correlation between NET_PROFIT and the related lag operator NET_PROFIT is very high (0.82) and expected to distort the estimated coefficients. Thus, lag value of NET_PROFIT is removed from the estimation equation.

Table 2: Pearson Correlations between the Variables Used in the Study

\begin{tabular}{lcccc}
\hline & NET_PROFIT & NET_PROFIT(-1) & TRS & TRS(-1) \\
\hline NET_PROFIT & 1.000000 & 0.820062 & 0.415855 & 0.437484 \\
NET_PROFIT(-1) & 0.820062 & 1.000000 & 0.301166 & 0.426598 \\
TRS & 0.415855 & 0.301166 & 1.000000 & -0.117166 \\
TRS(-1) & 0.437484 & 0.426598 & -0.117166 & 1.000000 \\
\hline
\end{tabular}

Panel A in Table 3 presents the results of OLS (ordinary least squares) estimation. The coefficient of TRS is negative and less significant than TRS(-1). Considering the relatively high correlation between TRS and TRS(-1), OLS estimation is repeated without TRS regressor (Table 3: Panel B). The magnitude and signs of estimated coefficients did not change substantially. 
Table 3: Results of Sensitivity Approach - Dependent Variable: $\Delta$ Comp

\begin{tabular}{|c|c|c|c|c|c|c|c|c|}
\hline Variable & $\begin{array}{c}\text { Panel A } \\
\text { OLS } \\
\text { Estimation }\end{array}$ & & $\begin{array}{c}\text { Panel B } \\
\text { OLS } \\
\text { Estimation }\end{array}$ & & $\begin{array}{c}\text { Panel C } \\
\text { Random } \\
\text { Effects EGLS } \\
\text { Estimation }\end{array}$ & & $\begin{array}{c}\text { Panel D } \\
\text { Cross - Section } \\
\text { Fixed Effects } \\
\text { Dummy Variable }\end{array}$ & \\
\hline $\mathrm{C}$ & 270691.8 & $* * *$ & 250151.2 & $* * *$ & 250151.2 & $* * *$ & 396049.4 & $* * *$ \\
\hline NET_PROFIT & 0.003552 & $* * *$ & 0.003248 & $* * *$ & 0.003248 & $* * *$ & 0.001963 & $* * *$ \\
\hline TRS & -0.000167 & * & & & & & & \\
\hline TRS(-1) & 0.000451 & $* * *$ & 0.000506 & $* * *$ & 0.000506 & $* * *$ & 0.000468 & $* * *$ \\
\hline Adjusted R-squared & 0.237001 & & 0.235307 & & 0.235307 & & 0.178634 & \\
\hline F-statistic & 100.3978 & & 148.7032 & & 148.7032 & & 2.430034 & \\
\hline Prob(F-statistic) & 0.000000 & & 0.000000 & & 0.000000 & & 0.000000 & \\
\hline Breusch-Pagan LM Test & & & 17.08025 & & & & & \\
\hline $\mathrm{p}$-value & & & 0.0000 & & & & & \\
\hline Hausman, $\chi^{2}$ test & & & & & 8.817766 & & & \\
\hline $\mathrm{p}$-value & & & & & 0.0122 & & & \\
\hline Observations & 961 & & 961 & & 961 & & 961 & \\
\hline
\end{tabular}

Without TRS variable, explanatory power of the regression only slightly declined (Adjusted $\mathrm{R}^{2}$ decreases to 0.2353 from 0.2370 ). On the other hand, OLS estimation presumes no correlation between explanatory variables and the error term of the regression equation. The Breusch-Pagan Lagrange multiplier test (Breusch and Pagan, 1980) indicates presence of heteroscedasticity (Table 2: Panel $\mathrm{B}, \mathrm{p}<0$ ). Therefore, variance of error terms seems to be dependent on the values of the independent variables, accordingly, firm or time specific effects seem to be important and OLS result is inefficient. The random effects estimation (Table2: Panel 3) provides efficient estimates under the assumption that the firm or time specific random effects are uncorrelated with the regressors. When these effects are correlated with the regressors, the results of random effects estimation are biased and inconsistent (Baltagi, 2008). Then, fixed effects estimator is the consistent estimator. The Hausman chi-square test (Hausman, 1978), comparing fixed effects and random effects estimators rejects the assumption that random effects are not correlated with the regressors (Table 3: Panel C; $\mathrm{p}<0$ ). Therefore, fixed effects estimation emerges as the efficient estimator for the selected equation.

Nevertheless, chosen model imparted quite similar results with three different estimators. The model explained roughly $20 \%$ of the variation in the level of compensation of executives/directors. Both accounting and market performance measures appear to be significant in the determination of the compensation of top executives/directors of firms. The estimations revealed that TL 10,000 lira return provided to shareholders in the previous year caused TL 5 increase in executives' total compensation, whereas TL 2 of TL 1000 current year net profit of the firms is given to the executives. It is well-known that firms distribute more generous bonuses when their operational profitability 
is higher and bottom-line figure is solid black. Furthermore, there seems to be a delay between the market performance and salary improvements and bonus payments. Yet, both accounting and market measures seem to play major role in the determination of executives' compensation level.

\section{Conclusion}

It is claimed that compensation contracts must be designed for the benefit of the principal to prevent possible agency costs. Theoretically, it is possible to link these contracts to both accounting or market measures, or a combination of the two. This study, based on observations of listed firms in Turkey, found that both accounting and market performance measures played significant roles in the determination of total executive pay. Current year's net profit level and lag value of chosen market measure, total shareholder return, roughly explained $20 \%$ of total executive compensation.

Top management of firms is generally compensated by a scheme which has both fixed and variable components. Performance allegedly affects the variable part, bonuses. Performance bonuses seem to be awarded with the achievements that are sensitive to both accounting and market measures. Unexplained portion of compensation might be stemming from fixed part of the contracts which are mostly insensitive to performance measures or bonuses tied to subjective unobservable performance measures.

The scope of this study is limited with listed and relatively bigger Turkish firms in different industries. It is not possible to generalize the results to all firms, especially to private firms. Private firms generally have different characteristics that differentiate their compensation means. Owners of private companies closely monitor and try to observe daily efforts of their executives. Close monitoring reduces the requirement for performance - related compensation. Thus, bonuses are subjectively determined based on the observed efforts of the executives.

As also exhibited by the results of this study, accounting and market measures are correlated. Market measures are forward-looking measures. Announcements that affect future profitability of the firm are immediately reflected in the current stock price. Thus, it is not surprising that contemporaneous accounting returns are correlated with lagged shareholder returns as also suggested by Murphy (1990). As both measures are highly significant in the regressions with relatively high correlation in between (0.44), it is not easy to judge on the relative weights of accounting and market-related measures in total compensation.

It is still a question mark that market-based incentives encourage executives to put more effort in the interest of shareholders. Because, it is easier to understand effects of own actions on accounting profits, but it is difficult to grasp effects of these actions on total shareholder value. Most managers focus on increasing accounting performance and devote less attention to market value, since they know how to affect the former but not the latter (Murphy, 1999). None of the existing studies succeeded to propose the primary driver of executive incentives. Although market based measures are theoretically better in aligning interests of shareholders and managers, we cannot conclude that majority of existing contracts are market-based rather than accounting based. Besides, existing compensation 
contracts, which are sharing only a fraction of created shareholder value with the agent cannot align the interests of both parties and mitigate the agency problem.

\section{REFERENCES}

ANG, James. S., \& CONSTAND, Richard. L. (1997). Compensation and Performance: the Case of Japanese Managers and Directors. Journal of Multinational Financial Management, 7(4), 275-304.

BEBCHUK, Lucian, A. \& FRIED, Jesse. M. (2003). Executive Compensation as an Agency Problem. The Journal of Economic Perspectives, 17(3), 71-92.

BALTAGI, Badi, H. (2008). Econometric Analysis of Panel Data. John Wiley \& Sons, 59-74.

BANGHOJ, Jesper., GABRIELSEN, Gorm., PETERSEN, Christian., \& PLENBORG, Thomas. (2010). Determinants of Executive Compensation in Privately Held Firms. Accounting \& Finance, 50(3), 481-510.

BERTRAND, Marianne., \& MULLAINATHAN, Sendhil. (2001). Are CEOs Rewarded for Luck? The Ones without Principals Are. The Quarterly Journal of Economics, 116(3), 901-932.

BLANCHARD, Olivier. J., LOPEZ-DE-SILANES, F., \& SHLEIFER, Andrei. (1994). What Do Firms Do with Cash Windfalls?. Journal of Financial Economics, 36(3), 337-360.

BREUSCH, Trevor. S., \& PAGAN, Adrian. R. (1980). The Lagrange Multiplier Test and Its Applications to Model Specification in Econometrics. The Review of Economic Studies, 47(1), 239-253.

CANARELLA, Giorgio., \& GASPARYAN, Arman. (2008). New Insights into Executive Compensation and Firm Performance: Evidence from a Panel of "New Economy" Firms, 1996-2002. Managerial Finance, 34(8), 537-554.

CANARELLA, G., \& NOURAYI, Mahmoud. M. (2008). Executive Compensation and Firm Performance: Adjustment Dynamics, Non-linearity and Asymmetry. Managerial and Decision Economics, 29(4), 293315.

CONYON, Martin. J., \& Leech, Dennis. (1994). Top Pay, Company Performance and Corporate Governance. Oxford Bulletin of Economics and Statistics, 56(3), 229-247.

CONYON, Martin. J., PECK, Simon. I., \& SADLER, Graham. (2000). Econometric Modelling of UK Executive Compensation. Managerial Finance, 26(9), 3-20.

CORE, John. E., HOLTHAUSEN, Robert. W., \& LARCKER, David. F. (1999). Corporate Governance, Chief Executive Officer Compensation, and Firm Performance. Journal of Financial Economics, 51(3), 371-406.

DECHOW, Patricia. M., \& SLOAN, Richard. G. (1991). Executive Incentives and the Horizon Problem: An Empirical Investigation. Journal of a-Accounting and Economics, 14(1), 51-89.

GAVER, Jennifer. J., \& Gaver, Kenneth. M. (1993). Additional Evidence on the Association between the Investment Opportunity Set and Corporate Financing, Dividend, and Compensation Policies. Journal of Accounting and Economics, 16(1-3), 125-160.

GUAY, Wayne. R., Core, John. E., \& LARCKER, David. F. (2003). Executive Equity Compensation and Incentives: A Survey. FRBNY Economic Policy Review, 27-50.

HARRIS, Jared. D. (2009). What's Wrong with Executive Compensation? Journal of Business Ethics, 85, 147-156.

HARRIS, Jared., \& BROMILEY, Philip. (2007). Incentives to Cheat: The Influence of Executive Compensation and Firm Performance on Financial Misrepresentation. Organization Science, 18(3), 350-367.

HAUSMAN, Jerry. A. (1978). Specification Tests in Econometrics. Econometrica: Journal of the Econometric Society, 1251-1271.

HEALY, Paul. M. (1985). The Effect of Bonus Schemes on Accounting Decisions. Journal of Accounting and Economics, 7(1-3), 85-107. 
HIMMELBERG, Charles. P., HUBBARD, R. G., \& PALIA, Darius. (1999). Understanding the Determinants of Managerial Ownership and the Link between Ownership and Performance. Journal of Financial Economics, 53(3), 353-384.

JENSEN, Michael. C., \& MURPHY, Kevin. J. (1990). Performance Pay and Top-management Incentives. Journal of Political Economy, 98(2), 225-264.

KOLE, Stacey. R. (1997). The Complexity of Compensation Contracts. Journal of Financial Economics, 43(1), 79-104.

MAIN, Brian. G., Bruce, Alistair., \& Buck, Trevor. (1996). Total Board Remuneration and Company Performance. The Economic Journal, 1627-1644.

MARCH, James. G. (1984). Notes on Ambiguity and Executive Compensation. Scandinavian Journal of Management Studies, 1(1), 53-64.

McCONNELL, John. J., \& SERVAES, Henri. (1990). Additional Evidence on Equity Ownership and Corporate Value. Journal of Financial Economics, 27(2), 595-612.

MEHRAN, Hamid. (1995). Executive Compensation Structure, Ownership, and Firm Performance. Journal of Financial Economics, 38(2), 163-184.

MISHRA, Chandra. S., McCONAUGHY, Daniel. L., \& GOBELI, David. H. (2000). Effectiveness of CEO Pay-for-Performance. Review of Financial Economics, 9(1), 1-13.

MURPHY, Kevin. J. (1999). Executive Compensation. Handbook of Labor Economics, 3, 2485-2563.

PALIA, Darius. (2001). The Endogeneity of Managerial Compensation in Firm Valuation: A Solution. The Review of Financial Studies, 14(3), 735-764.

SLOAN, Richard. G. (1993). Accounting Earnings and Top Executive Compensation. Journal of Accounting and Economics, 16(1-3), 55-100.

YERMACK, David. (2006). Flights of Fancy: Corporate Jets, CEO Perquisites, and Inferior Shareholder Returns. Journal of Financial Economics, 80(1), 211-242.

ZHOU, Xianming. (1999). Executive Compensation and Managerial Incentives: A Comparison between Canada and the United States. Journal of Corporate Finance, 5(3), 277-301. 